\title{
New histochemical and morphological findings in the female genital tract of Boophilus microplus (Acari, Ixodidae): an attempt toward the elucidation of fertilization in ticks
}

\author{
Casimiro García-Fernández ${ }^{1}$, Sonia M. Lauer de Garcia ${ }^{1}$, Rosane Nunes Garcia ${ }^{2}$ \& \\ Vera L. da Silva Valente ${ }^{2}$
}

1. Departamento de Ciências Morfológicas, Instituto de Ciências Básicas da Saúde, Universidade Federal do Rio Grande do Sul, Rua Sarmento Leite, 500, 90050-170 Porto Alegre, RS, Brazil. (caseygarfer@yahoo.com.br)

2. Departamento de Genética, Av. Bento Gonçalves, 9500, prédio 43323, Caixa Postal 15053, 90510-002 Porto Alegre, RS, Brazil.

\begin{abstract}
At present not only is the site of fertilization in ticks still unknown but it is also unclear as to how this mystery can be solved. Signs of fertilization can be observed throughout the female genital tract and these can be clues for the elucidation of the unsolved questions relating to ticks fertilization. In Boophilus microplus (Canestrini, 1887) the most important signs are the following: the final eversion of the acrosomal canal in females ready for oviposition; the presence of small tubules, resembling the subplasmalemal process of the spermatozoon between the oviduct cells; budding nuclei throughout the female genital tract; and the two Feulgen and DAPI positive areas in the oocyte at vitelogenesis. These morphological characteristics suggest that fertilization takes place in the internal cylinder which extends from the uterus to the ovary itself.
\end{abstract}

KEYWORDS. Acari, ticks, female reproductive system, fertilization.

RESUMO. Novas características histoquímicas e morfológicas no trato genital feminino de Boophilus microplus (Acari: Ixodidae): uma tentativa para a elucidação da fertilização nos carrapatos. Até o momento, não só o lugar da fertilização em carrapatos é desconhecido, mas também não é claro como este mistério possa ser esclarecido. Sinais de fertilização podem ser observados ao longo do trato genital feminino e estes podem ser pistas para a elucidação das questões relacionadas à fertilização em ácaros. Em Boophilus microplus (Canestrini, 1887), os sinais mais importantes são os seguintes: a eversão final do canal acrossômico em fêmeas prestes à oviposição; a presença de pequenos túbulos assemelhando-se a processos subplasmalêmicos dos espermatozóides entre as células do oviduto; brotamentos nucleares ao longo do trato genital feminino e as duas áreas Feulgen e DAPI positivas nos ovócitos em processo de vitelogênese. Estas características morfológicas sugerem que a fertilização ocorra no cilindro interno, o qual se estende desde o útero até o ovário inclusive.

PALAVRAS-CHAVE. Acari, carrapatos, aparelho reprodutor feminino, fertilização.

In ticks, the precise site of fertilization and the mechanism by which male gametes encounter the oocyte are still unknown. Some researchers have suggested that fertilization occurs in the oviducts, as is the case in Ornithodoros moubata (Murray, 1877) (WAGNERJEVSEENKo, 1958), although Goroschenko (1965) apud BALASHOv (1972) as stated that the ampulla region is the precise site of fertilization in this tick. In the Ixodoidea there is no ampulla and fertilization takes place in the anterior third of the oviduct (BALASHOv, 1972), suggesting that the oocyte is fertilized as it passes through this region during oviposition. In the Ixodid tick Boophilus microplus (Canestrini, 1887), GarCía-FERnÁNDEZ et al. (2001) found evidence that at oviposition the ova are in an advanced stage of cleavage, proving that fertilization occurs prior to oviposition.

That fertilization can occur in the ovary has been suggested by several workers (LEES \& BEAMENT, 1948; Khalil, 1969,1970; Brinton \& Oliver, 1971a, b). Oliver \& BRINTON (1973) and BRINTON et al. (1974) observed spermatozoa during their migration to the ovary and noted their tendency to actively penetrate not only the epithelial cells lining the ovary lumen but also those lining the oviduct.

In B. microplus, spermatozoa are progressively encountered throughout the female genital tract, from the uterus to the ovary depending on the degree to which the female is engorged. At the very beginning of engorgement the spermatozoa are found throughout the genital tract from uterus to the ovary but as engorgement progresses the spermatozoa are impeded from proceeding toward the ovary by the formation of a ring-like structure in the oviduct close to the ovary (GARCíA-FERNÁndEZ et al., 1999, 2001), the access to the ovary occurring when this structure disappears and the female is ready for ovulation.

There is also controversy about the mechanism of fertilization itself. Goroschenko (1965) apud BALASHOv (1972) claims that in the argasids only the nucleus of the spermatozoon penetrates the oocyte, the rest of the spermatozoon being dissolved by secretions produced by epithelial cells on the walls of the oviduct and uterus. KHALIL (1969) suggests that in Argas (Persicargas) arboreus (Kaiser, Hoogstraal \& Kohls, 1968) the spermatozoon actively penetrates the primary oocyte (where it can be seen as being less basophilic than the cytoplasm of the oocyte) and degenerates, leaving only its nucleus which can be seen as a basophilic area of darkly-staining lumps of chromatin. In the ixodid Dermacentor andersoni (Styles, 1902), active penetration 
of oocytes by spermatozoa through a structure similar to a micropyle has been suggested by various workers (BRINTON \& OlIVER, 1971a, b; OlIVER \& Brinton, 1973; Brinton et al., 1974; Oliver, 1974; SonEnshine, 1991), suggesting that only the small nucleus enters the oocytes and that the remaining tubular part of the spermatozoon does not participate in fertilization but is dissolved by secretions of the glandular epithelium of the oviduct and uterus walls.

Intimate associations between spermatozoa and epithelial cells of the oviduct wall have been observed by Sokolov (1956), suggesting that ixodid tick spermatozoa penetrate oviduct cells to obtain nutrients. Spermatozoa have been seen in many different cells throughout the female genital tract and it is likely that they indeed actively penetrate cells (OLIVER \& BRINTON, 1973; BRINTON et al., 1974). Phagocytosis of spermatozoa by cells of the wall of the oviduct has also been reported by some authors, e.g. Aeschlimann (1958) in O. moubata and TILL (1961) in Rhipicephalus appendiculatus (Neumann, 1901).

GARCíA-Fernández et al. (1999) described the oviduct of $B$. microplus as being formed by two concentric cylinders made up of different cell types, with the internal cylinder extending throughout the whole female genital tract from the oviducts to the ovary. These authors have also suggested that the internal cylinder functions as a germarium, while the ovary acts as a vitellarium, with fertilization occurring throughout the internal cylinder (GARCÍA-FERNÁNDEZ et al., 2001).

In spermatozoa, invagination of the acrosomal canal has previously been interpreted as a flagellum by various authors (SAMSOM, 1909; CASTEEL, 1917; OPPERMANN, 1935; TuZET \& Millot, 1937; Sharma, 1944) but it is now seen as an acrosome which invaginates when the sperm cell reaches the oviduct (REGER, 1963; KHALIL, 1969, 1970; Brinton et al., 1974; Feldman-Muhsam \& Filshie, 1976; Suleiman \& Brown, 1978; El SAID \& Swiderski, 1980; EL SHOURA, 1987). In B. microplus, it has yet to be elucidated if the nucleus of the spermatozoa (which lies lateral and adjacent to the acrosomal canal) passes to the interior of the acrosomal canal and if this canal is everted at the time of fertilization, as described by PINKERTON et al. (1982) in the soft tick $O$. moubata.

Spermatozoon movement has been characterized as rotatory and worm-like by SHARMA (1944), gliding by RothSCHILD (1961) and REGER (1974) and 'rolling-up and folding out' by EL SAID \& SwIDERSKI (1980). The structures involved in this movement are the cellular processes (RoTHSCHILD, 1961; REGER, 1974) running parallel to the long axis of the spermatozoon, the bulbous hemisphere of the anterior tip of the spermatazoa, for which EL SAID \& SwIDERSKI (1980) suggested a tactile function, and the clavate region in which the mitochondria are crowded and which represents the active end with which the sperm moves forward followed by the tail region.

In ticks, the process by which fertilization proceeds is still largely unknown but a deeper understanding of this matter is important because it may provide insight into how the fertility of ticks is controlled, which in turn may lead to biotechnological measures for the control of tick populations. Our study aimed at providing more information on the fertilization processes in the tick Boophilus microplus.

\section{MATERIAL AND METHODS}

Ticks were collected from naturally infected cows pastured on a farm near the town of Viamão, Rio Grande do Sul, Brazil. In the laboratory the reproductive organs (spermatheca, uterus, oviducts and ovary from females; testis from males) were dissected out in Shen's saline (containing (g/l); $\mathrm{NaCl}, 9 ; \mathrm{KCl}, 0.42 ; \mathrm{CaCl}_{2}, 0.25$ ).

For squash-mounts the reproductive apparatus was fixed in absolute alcohol:glacial acetic acid (3:1) and squashed in a drop of $45 \%$ acetic acid between a cover slip and slide, the cover slip being removed by the normal 'dry-ice' method. Specimens were stained using the Feulgen reaction (FEULGEN \& RossENBECK, 1924), periodic acid and Schiff reagent (PAS) and hematoxylin or aceticorcein (LA CouR, 1941) and counter-stained with fastgreen. Spermatozoa (obtained by piercing different regions of the ovary when the ring-like structure had disappeared) were immersed in a drop of saline placed on a glass slide, air-dried and stained with PAS and hematoxylin. These specimens were examined under light microscope at an appropriate magnification.

In order to see the movement of the spermatozoa, the oviducts from the middle engorged females were isolated and observed between a cover slip and slide in a drop of saline under phase contrast microscopy. In some places the oviduct was broken by moderate pressure applied to the cover slip and some spermatozoa became partially or totally free.

For fluorescence microscopy, squash mounts were prepared as above and immersed for one hour in 1:1 DAPI (4'-6-diamino-2-phenylindole):McIlvaine buffer (Schweizer, 1980, 1981 and Pieczarka et al., 1996), mounted in 1:1 glycerol:McIlvaine buffer and examined under a fluorescence photomicroscope equipped with a G365 FT 395 LP 420 Zeiss filter.

Material for sectioning was fixed either in $4 \%$ paraformaldehyde or $3 \%$ gluteraldehyde and $1 \% \mathrm{OsO}_{4}$ in $0.1 \mathrm{M}$ sodium phosphate buffer ( $\mathrm{pH} 7.4)$. The material fixed in paraformaldehyde was embedded in glycol-metacrylate and cut into 2-3 $\mu \mathrm{m}$ sections on a RMC ultratome using a dry diamond knife and stained either with hematoxylin and eosin or by the PAS hematoxylin method. The material fixed in gluteraldehyde and $\mathrm{OsO}_{4}$ was embedded in epon and semi-thin sections were stained with toluidin blue. Thin sections were obtained from testis stained with uranyl acetate and lead citrate and examined using transmission electron microscopy.

\section{RESULTS}

Modification in the structure of spermatids from the testis to the ovary. When the spermatids arrive at the spermatheca they are comma-like as in the testis with the nucleus extending in a spiral throughout the length of the spermatid (Fig. 1), within the testis the nucleus is located between the plasma membrane and the subplasmalem processes (Fig. 2). In the anterior portion of the spermatid (the clavate or paddle region) 
microtubules can be observed (Fig. 3). The spermatheca is the portion of the female genital tract where eversion of the inner core of the spermatid as well as the invagination of the acrosomal canal and the consequent relocation of the nucleus below the cellular processes take place (Fig. 4). In the uterus and oviducts, capacitation of the spermatozoa continues as can be seen by the different degrees of chromatin condensation ending in a fine filament with a knob at its extremity (Figs. 5-7). When the oviduct was broken in such a way that some of the spermatozoa were only partially released, the free spermatozoa showed a light oscillating movement with the paddle region generally oriented toward the exterior of the oviduct while those spermatozoa which were completely free from the oviducts did not show such a movement. During the last step in capacitation, the eversion of part of the acrosomal canal can be seen in the ovary (Figs. 8, 9).

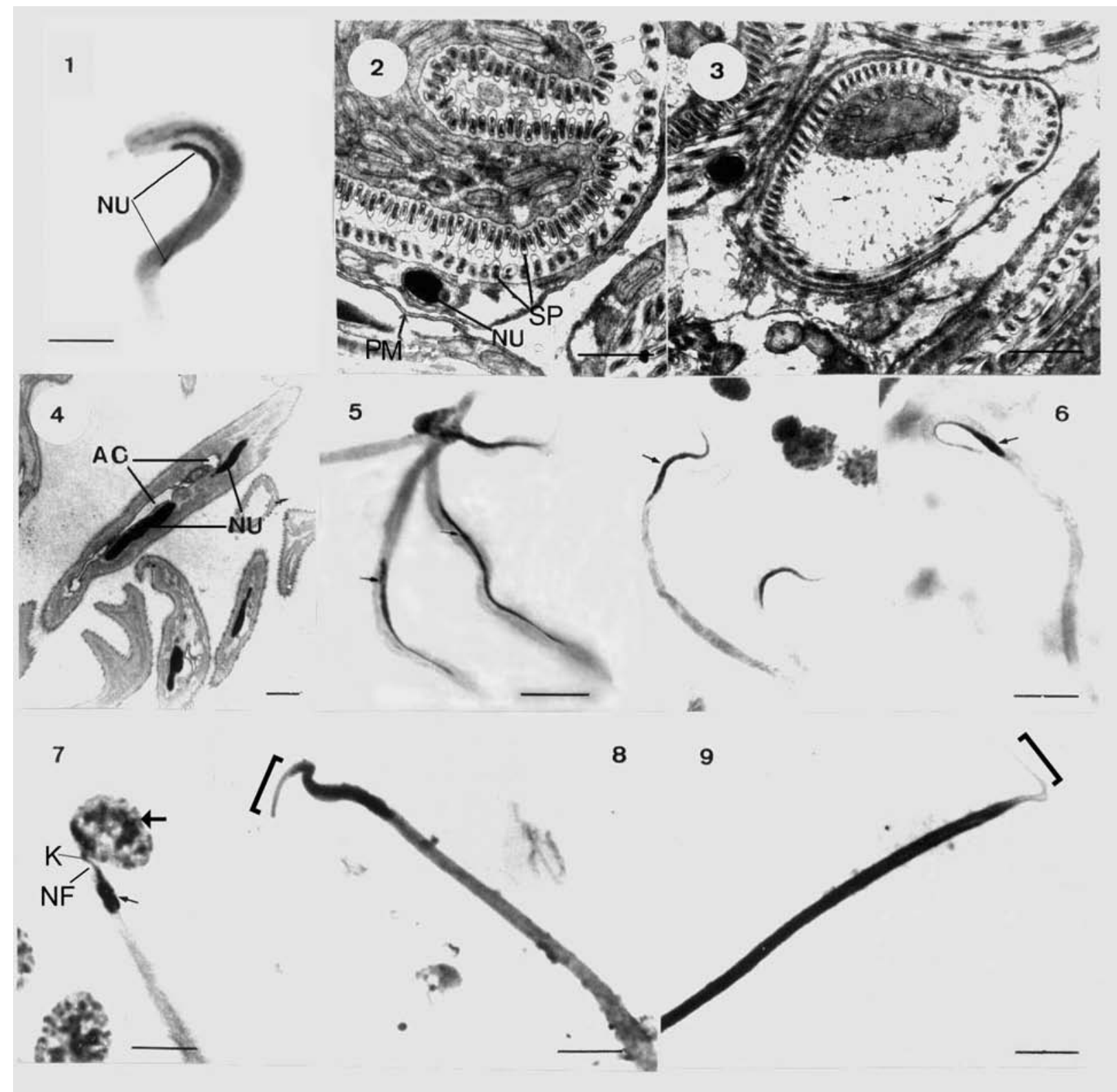

Figs. 1-9. Spermatids in the testis and their modifications throughout the female genital tract from the spermatheca to the ovary. 1, in the spermatheca, spermatid before eversion is comma-like and has a nucleus extending as a spiral throughout its length; 2, transversal thin section of a spermatid from the testis, showing the nucleus between the plasma membrane and the subplasmalem process; 3 , microtubules (arrows) in a transversal thin section of the clavate region of the spermatid from the testis; 4 , longitudinal thin section of an everted spermatid from the oviduct, the nucleus is located paralel to the acrosomal canal; 5, 6, progressive nuclear condensation (arrows) of spermatozoa from the uterus to the oviducts of females in the process of engorgement; 7 , full nuclear condensation (thin arrow) of spermatozoon in the oviduct of a female in the process of engorgement with the knob at the end of the nuclear filament contacting the oocyte nucleus (thick arrow); 8, 9, partial eversion of the acrosomal canal (brackets) in mature and fully capacitated spermatozoon in the ovary of fully engorged females. (AC, acrosomal canal; K, knob; NF, nuclear filament; NU, nucleus; PM, plasma membrane; SP, subplasmalem processes). Figs. 1, 5-7, squashes stained with PAS-hematoxylin; Figs. 2, 3, electron microscope sections of spermatids; Figs. 8-9, spermatozoa obtained by piercing ovary tissue at the end of engorgement PAS-hematoxylin. Figs. 1, 4-9, bar, $10 \mu \mathrm{m}$; Figs. 2, 3, bar, $2 \mu \mathrm{m}$. 
Interactions between spermatozoa and cells of the uterus, oviduct and ovary. There are two clearly different parts in the tick spermatozoon, the head and the tail; the head being the part of the spermatozoon ending in the bulbous hemisphere and the tail the part which brings the sperm nucleus. There is an evident contact between spermatozoa and cells that form the internal cylinder (Figs. 10-12) which extends into the interior of the ovary. The sperm cell adheres to the female cell by its head, that is, by the bulbous hemisphere (Fig. 12), as well as by the tail-like region (Figs. 13-15).

While the spermatozoa are free in the internal cylinder their nuclei are uniformly thin and long (Figs. 10, 11) but when the tail of spermatozoa touches the oviduct internal cells, condensation and retraction of the nucleus of the spermatozoon in the direction of the oviduct cells can clearly be seen and it can be noted that the thin part of the nuclear filament which ends in a knob is the first part to adhere to the cell.

Tangential sections of the oviduct also show that dense structures related to the spermatozoa appear pressed among the cells of the internal cylinder. Many small transversely-cut tubules can be seen which are similar to the characteristic cellular processes of the

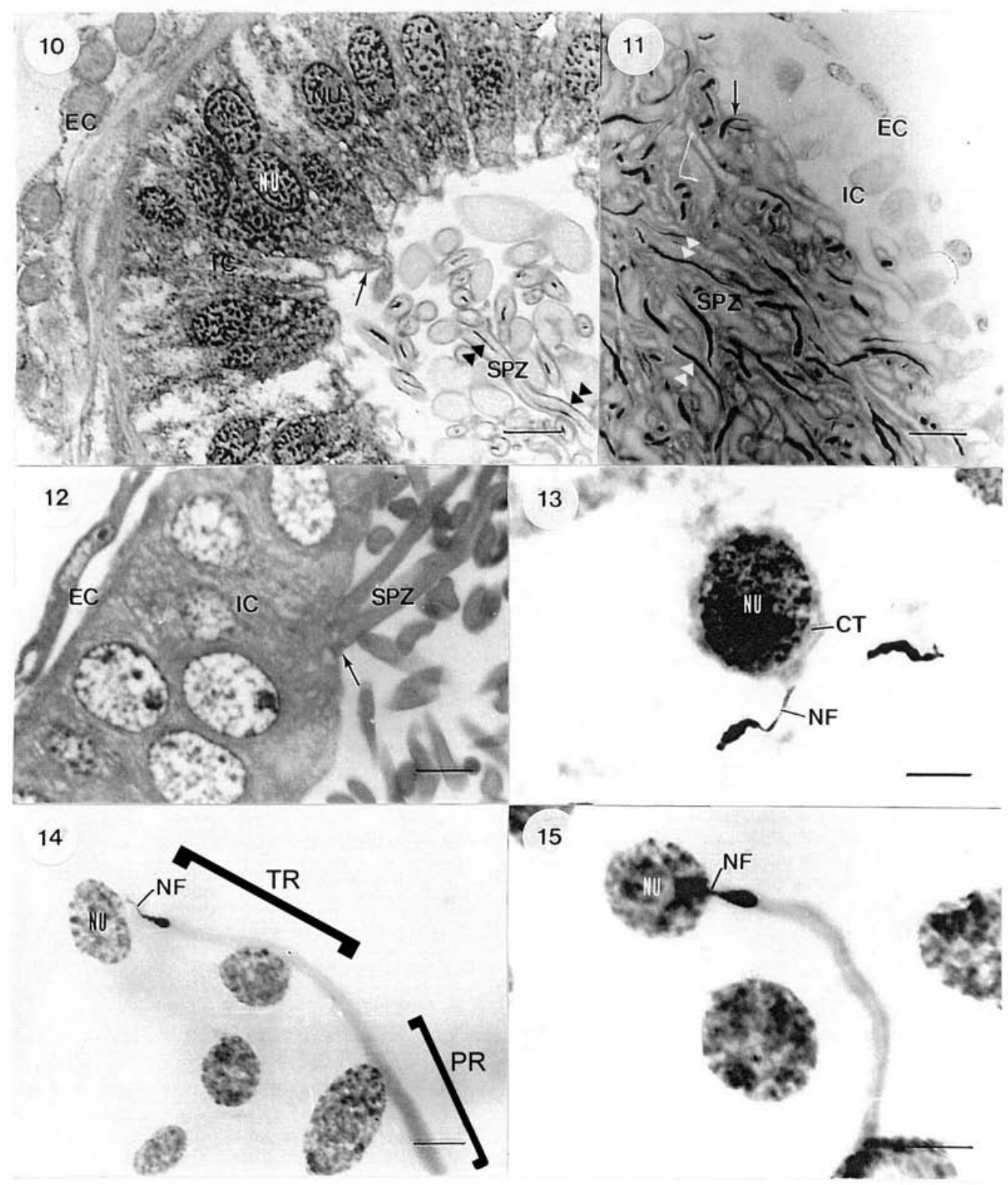

Figs. 10-15, close contact of spermatozoa with the internal cylinder cells (arrows), the arrow in figure 12 indicates where the bulbous hemisphere of the head of the spermatozoa is adhered to the internal cylinder cells. Nuclei of free spermatozoa in the lumen are thin and long (head arrows); 13-15, adhesion of the tail-like region of spermatozoon to the oviduct cells. Spermatozoa nuclei become more condensed and retracted (CT, cytoplasm oviduct cell; EC, external cylinder; IC, internal cylinder; NF, nuclear filament; NU, female cell nucleus, PR, paddle region; SPZ, spermatozoon; TR, tail-like region). Fig. 10, glycolmethacrylate section stained with hematoxylineosin; Fig. 11, glycolmethacrylate stained with Feulgen-fast-green; Fig. 12, epon semi-thin section stained with toludine blue; Fig. 13, orcein-fast-green squash; Figs. 14, 15, PAS-hematoxylin squashes. All the figures are from oviduct, except Fig. 11 which is from the uterus. Bar, $10 \mu \mathrm{m}$. 
spermatozoa (Figs. 16, 17). Large, well-delineated vesicles can also be seen which are filled with densely stained homogeneous material, these vesicles being inside another, non-homogeneous, structure which is also delineated by a wall (Fig. 17).

The presence of spermatozoa close to ovarian cells can be observed in the internal cylinder which also extends to the interior of the ovary (Figs. 18, 19). Budding nuclei of the oviduct cells can be seen in both squash mounts (Figs. 20-23) and histological sections (Fig. 24).

Structural modifications of oviduct cells. Structural modifications occur in the oviduct internal cylinder cells which maintain contact with spermatozoa. The form of the cells of the internal cylinder depends upon the quantity of the spermatozoa in the lumen of the oviduct. When the spermatozoa are not crowded in the lumen, the cells of the internal cylinder are columnar (Fig. 10) but when the spermatozoa are crowded, forming masses in the lumen, they are pressed against to the cells of the internal cylinder and the cells become cubical and filled with small vesicles which give rise to larger vesicles and, ultimately, one big vesicle (Figs. 25, 26). A globular structure (sometimes very basophilic, sometimes only moderately so) can be seen inside the large vesicle, and also a clear granulation inside the less basophilic globular structures (Fig. 26).

In the ovary, at the beginning of vitellogenesis, globular structures with basophilic granulation similar to that described in the previous paragraph can also be seen (Fig. 27). Oocytes in the process of vitellogenesis (Balashov stage III, i. e. at the beginning of the appearance of many small yolk-granules) present two

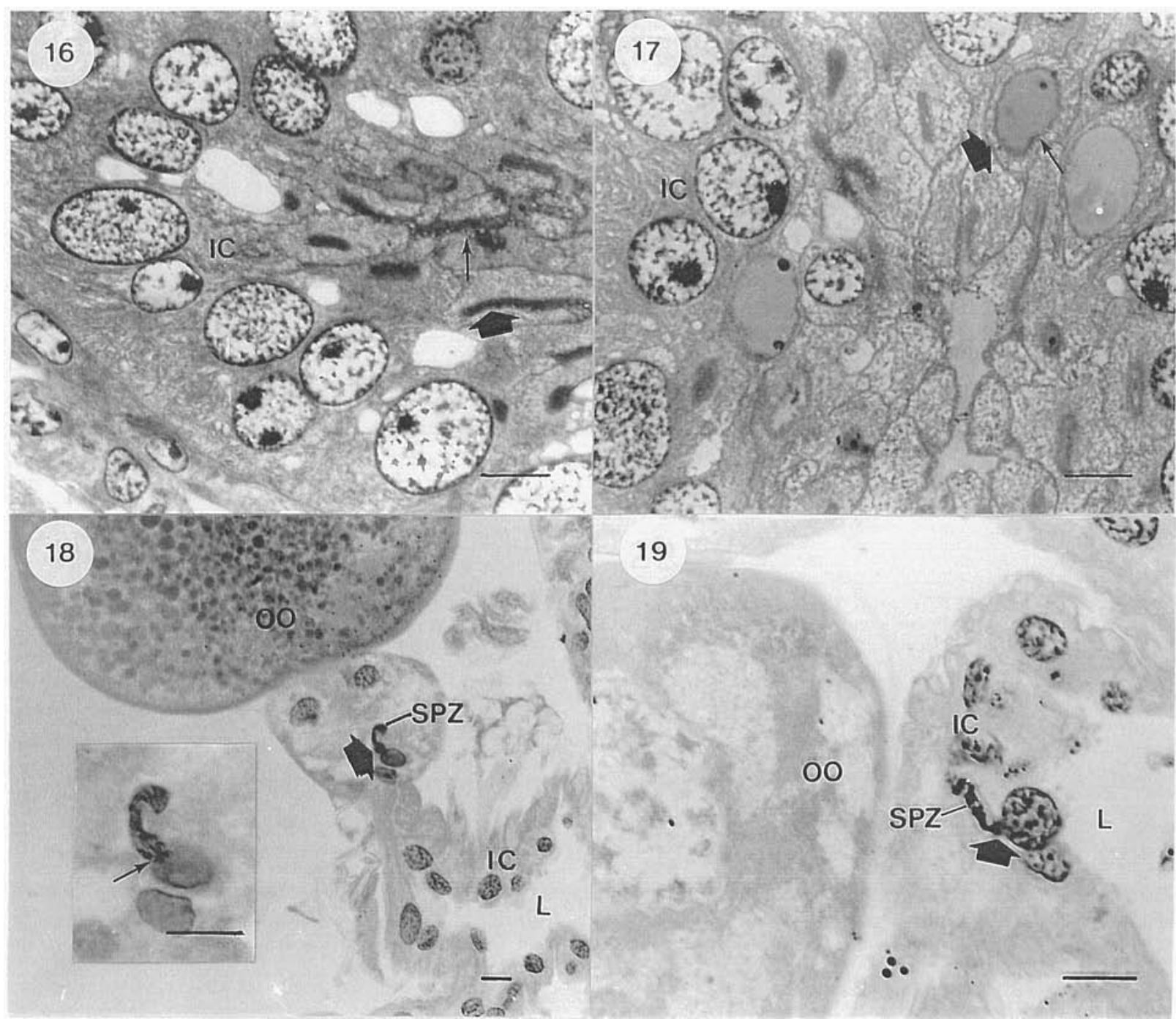

Figs. 16-19, semi-thin tangential sections of a region of the oviduct near the uterus: 16, dense structures projecting towards the interior of the internal cylinder (thick arrow) and small transversely-cut tubules forming part of the walls of the dense structures (thin arrows); 17, large, clearly delimited vesicles filled with an homogeneous dense material containing densely stained structures (thin arrows), the large vesicles being inside another non-homogeneous structure delimited by a wall (thick arrow). 18, 19, ovaries from females close to ovulation, clearly showing contact between the spermatozoa and the ovary cells (thick arrow). The inset in the figure 18 shows the section in detail, where an accumulation of PAS positive granules can be seen in the region of contact as well as longitudinal processes issuing from the spermatozoon (IC, internal cylinder; L, lumen; OO, oocyte; SPZ, spermatozoon). Figs. 16, 17 are semi-thin epon sections stained with toludine blue. Figs. 18, 19 are glycol-metacrylate sections stained with PAS-hematoxylin Bar, $10 \mu \mathrm{m}$. 
Feulgen-positive areas opposite to each other, although the nucleus itself is not Feulgen-positive, appearing only as a faint structure (fig. 28). The same Feulgen-positive areas are present when stained with DAPI (Fig. 29).

\section{DISCUSSION}

Spermatozoa in both ixodids and argasids undergo a series of modifications within the female genital tract, one of these being the opening of the operculum at the anterior extremity of the spermatozoa which allows eversion of the inner core (OLIVER \& BRINTON, 1973) and the formation of the acrosomal canal (WÜEST et al., 1978). Some authors distinguish a final step in the morphological differentiation of spermatozoa of various argasids, e.g. eversion of the acrosomal canal before penetration of the oocyte and relocation of the nucleus to the interior of the eversion (CASTEEL, 1917; OPPERMANN, 1935; WAGNERJevseenKo, 1958; Khalil, 1969; Feldman-Muhsam \& Filshie, 1976; Oliver, 1982; PinKerTon et al., 1982).

One step in the capacitation of B. microplus spermatozoa seems to be the partial evagination of the acrosomal canal, here observed for the first time in ixodids. In the argasid Argas miniatus (Koch, 1844) the evagination of the acrosomal canal (misinterpreted as a flagellum by CASTEEL, 1917) occurs while the spermatozoa are within the spermatophore sac in the spermatheca. In Ornithodoros moubata, (PINKERTON et al., 1982) and in Ornithodoros tholozani (Tholozan, 1879) and Ornithodoros gurneyi (Warburton, 1926) (FELDMANMuHSAM \& FILSHIE, 1976), the acrosome evaginates only when the sperm cell has reached the oviduct, this having also been noted in Argas miniatus by KHALIL (1969). In $B$. microplus the evagination of the acrosomal canal was observed in the ovary and only at the time of ovulation. The reason why the acrosome remains hidden within the sperm cell for most of the time is unknown but this may facilitate transport of the sperm through the genital tract and the preservation of acrosomal enzymes. The eversion of the acrosomal canal might be an event signaling the encounter of the male and female gametes, i.e. fertilization.

Another step in sperm capacitation in B. microplus may be the progressive condensation of its nucleus in the direction of the tail-like region, although it should be

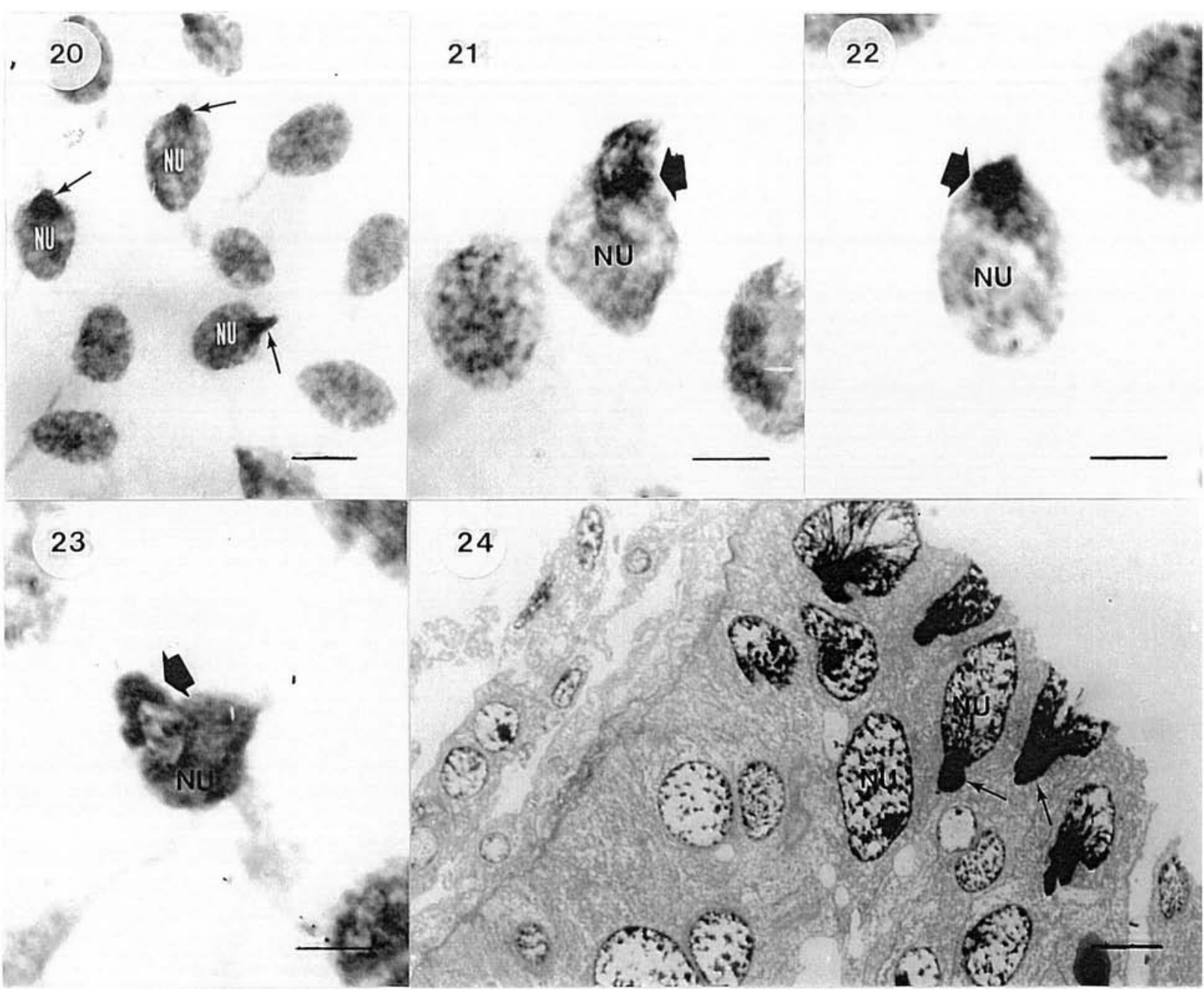

Figs. 20-24, feulgen-stained squash mounts of the internal cylinder of oviducts suggesting fusion of the spermatozoa with the female cell nuclei; 24, a section of the region corresponding to the squashes shown in Figs. 20-23, suggesting fusion between the spermatozoa and female cell nuclei (epon-toludine blue). Arrows indicate spermatozoa nuclei (NU, oviduct cell nucleus). Bar, $10 \mu \mathrm{m}$. 


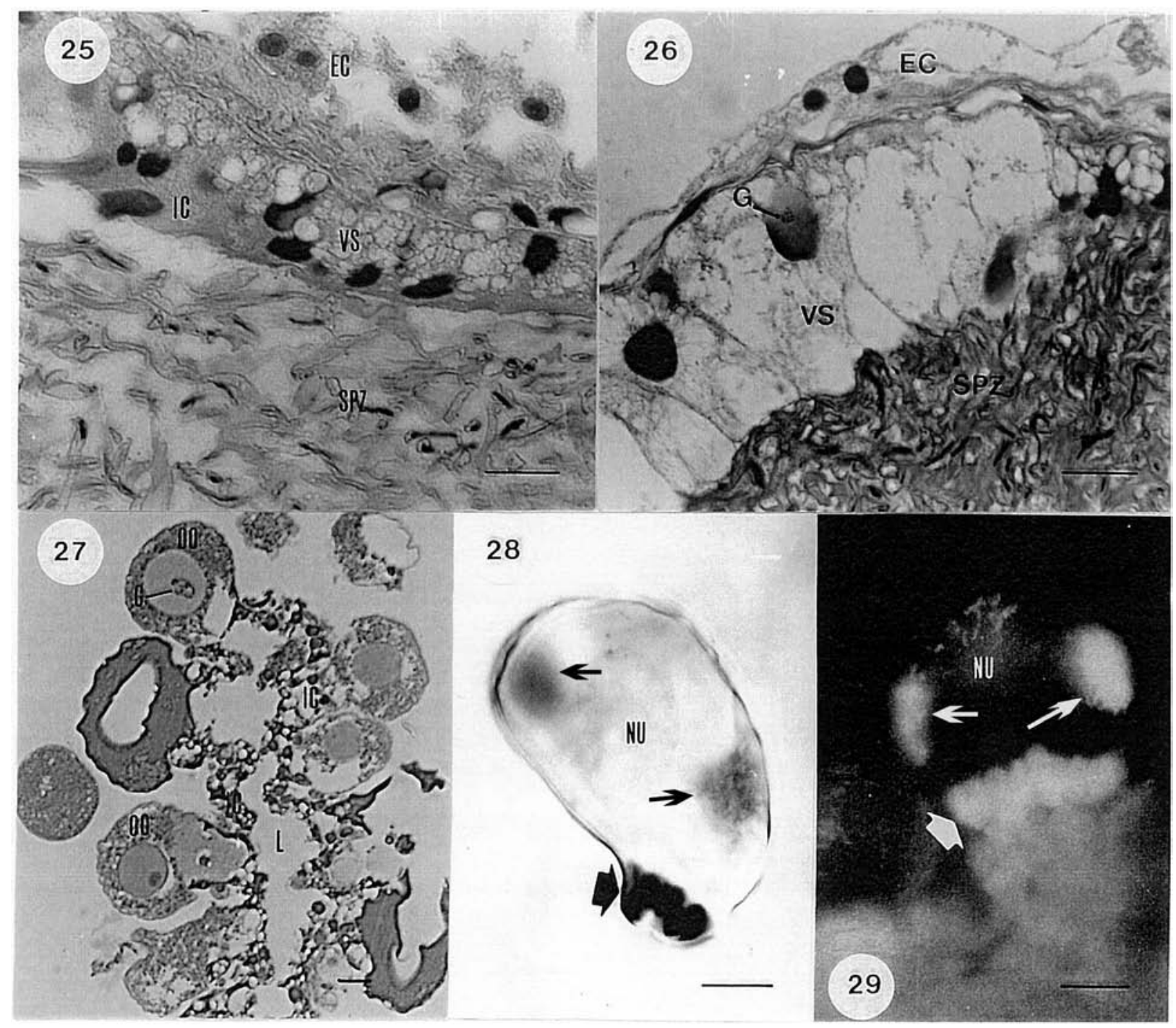

Figs. 25-29, the lumen of the oviduct showing many spermatozoa in close contact with the cells of the internal cylinder, that are filled with vesicles of different sizes; 26, the mass of spermatozoa is being retracted and the small vesicles have fused into big vesicles and in the interior of theses big vesicles are globular structures with granulation visible inside them; 27 , ovary at the beginning of vitellogenesis with basofilic granulation in globular structures similar to that of Fig. 26. Figs. 25, 26 are semi-thin sections of oviducts in the process of engorgement stained with hematoxylin-eosin; Fig. 27 is a semi-thin section of the ovary of a normally-engorged female stained with hematolxylin-eosin; 28, Feulgen-stained mount of an oocyte in the process of vitellogenesis isolated from the ovary with the two Feulgen-positive areas (thin arrows) opposite each other. The nucleus is the faint Feulgen negative structure. The funicular cells rest at the base of the oocyte (thick arrows); 29, DAPI stained mount of an oocyte from a portion of the ovary lightly squased in the process of vitellogenesis with two DAPI positive areas (thin arrows) opposite each other, corresponding to the Feulgen positive areas in Fig. 28. The nucleus is the faint structure and the funicular cells resting at the base of the oocyte are DAPI positive (thick arrow). (EC, external cylinder; G, granules; IC, internal cylinder; L, lumen; NU, nuclear zone; OO, oocytes; SPZ, spermatozoa; VS, vesicles). Bar, $10 \mu \mathrm{m}$.

pointed out that what many authors refer to as the taillike region should in fact be looked upon as the morphological head, as suggested by CASTEEL (1917). The fine filament which emerges from the nucleus and terminates in a knob-like structure could be related to the adhesion to oocytes.

In elucidating the mechanism of fertilization in ticks it is important to know how the spermatozoon reaches the oocyte. Several researchers have described the active movement of spermatozoa (RoTHSCHILD, 1961; REGER, 1974; Feldman-Muhsam \& Filshie, 1976; El Said \& SwIDERSKI, 1980), this movement appearing to be related to either undefined cellular processes or the longitudinally-oriented fibrils which run beneath the cell membrane of the sperm (FELdman-MuHSAM \& FiLShie, 1976). Our observations of semi-thin and thin sections of individual B. microplus spermatozoa within the lumen of oviducts confirm that they have inherent movement, based on the multiple forms which they display in sections. When the intact oviduct was mounted in saline and observed using phase-contrast microscope, masses of living spermatozoa were clearly seen moving down the oviduct. This suggests that the movement of the sperm cell, named translatory movement by FELDMANMunsam \& Filshie (1976), is passive and caused by peristalsis of the oviducts. The end of the clavate region 
of the individual spermatozoon is the only part of the living cell which can be observed actively moving and its function still remains unknown. It can be suggested that the adhesion of the bulbous region of the spermatozoon to the ovary wall might represent a necessary mechanism involved with the movement of the sperm cell. The presence of microtubules in this region may be related to the movement of this part of the sperm. Reger (1974) failed to find microtubules in Dermacentor andersoni at any stage of development. Microtubules, however, are clearly seen in the spermatid of some species of spiders (AlberTI, 1995).

Based on the presence of cells with budding nuclei from the oviduct to the ovary, our results suggest that the spermatozoon contacts with the oocyte in the germarium in different regions of the genital tract. Budding nuclei might be indicative of syngamy as shown by the fact that they appear in oviduct cells only near spermatozoa and that, in the ovary, budding nuclei appear in the interstitial cells which are the first cells to make contact with spermatozoa coming through the lumen of the ovary. We suggest that cells with budding nuclei are cells of the internal cylinder (GARCÍA-FERNÁNDEZ et al., 1999, 2001), which extends itself into the ovary. Budding nuclei representing expulsion of DNA from the female nucleus as an alternative to reductional divisions seems very improbable. The cells containing nuclei with highly diffused chromatin observed in the external wall of the external cylinder could represent the next step after fertilization, these cells moving to the ovary (vitellarium), where vitellogenesis occurs.

Feulgen-positive areas outside the nucleus were observed in O. moubata by GeIGY \& WAGNER (1957) and WAGNER-JEWSEENKO (1958), who interpreted these areas as being DNA particles discharged from the nucleus, but in Argas persicus (Oken, 1818) (Roshdy, 1961) and Hyalomma asiaticum Schulze \& Schlottke, 1929 (BALASHOv, 1972), these areas are believed to represent rickettsiae. In the case of B. microplus, Feulgen and DAPIpositive areas are found in the eggs at phase III of vitellogenesis (BALASHOv, 1972). Our results show unequivocally that these Feulgen-positive areas are DNA, and the fact that the location of these areas are both specific and constant tells us that they are neither rickettsiae nor simple extrusions of DNA as has previously been suggested. Furthermore, when these Feulgen-positive areas are observed in the egg, the nucleus of the egg is no longer Feulgen-positive. These cytoplasmic DNA areas could represent either the two pro-nuclei or the two nuclei in process of cleavage. We do not have yet unequivocal evidence for excluding either of these two hypotheses but the presence of a Feulgennegative nucleus between these two DNA positive areas favors the second hypotheses, suggesting that the fusion of pro-nuclei takes place before the beginning of vitellogenesis.

\section{REFERENCES}

Aeschlimann, A. 1958. Développement embryonaire d'Ornithodoros moubata (Murray) et transmission transovarienne de Borrelia duttoni. Acta Tropica Parasitologie 15(1):15-64.
Alberti, G. 1995. Comparative spermatology of Chelicerata: review and perspective. In: Jamieson, B. G. M,; Ausio, J. \& Justine, J. L. eds. Advances in Spermatozoal Phylogeny and Taxonomy. Mémoires du Muséum National d'Histoire Naturelle 166:203-230.

Balashov, Y. S. 1972. Bloodsucking ticks (Ixodoidea) vectors of disease of man and animals (English translation). Miscellaneous Publications of the Entomological Society of America 8:161-376.

Brinton, L. P. \& Oliver, J. H., JR. 1971a. Gross anatomical, histological, and cytological aspects of ovarian development in Dermacentor andersoni Stiles (Acari: Ixodidae).The Journal of Parasitology 57(4):708-719. 1971b. Fine structure of oogonial and oocyte development in Dermacentor andersoni Stiles (Acari: Ixodidae). The Journal of Parasitology 57(4):720-747.

Brinton, L. P.; Burgdofer, W. \& Oliver, J. H., JR. 1974. Histology and fine structure of spermatozoa and egg passage in the female tract of Dermacentor andersoni Stiles (Acari: Ixodidae). Tissue and Cell 6:109-125.

Casteel, D. B. 1917. Cytoplasmic inclusion in male germ cell of the fowl tick. Journal of Morphology 28:643-683.

EL SAID, A. \& Swiderski, Z. 1980. Regional specialization of the sperm membrane in the tick Amblyomma hebreum Koch (Acari: Ixodidae). Cell and Tissue Research 208: 35-45.

EL Shoura, S. M. 1987. Spermatogenesis ultrastructure in the tick Argas (Persicargas) arboreus (Acari: Ixodoidea: Argasidae). Journal of Medical Entomology 24:532535

Feldman-Muhsam, B. \& Filshie, B. K. 1976. Scanning and transmission electron microscopy of the spermiophores of Ornithodoros ticks: an attempt to explain their mobility. Tissue and Cell 8(3):411-419.

Feulgen, R. \& Rossenbeck, H. 1924. Mikroskopisch-chemischer Nachweis eine Nucleinsäure von Typus der Thymonucleinsäure und die darauf beruhend Elektive Färbung von Zellkernen in mikroskopischen Präparaten. Zeitschrift für Physiology Chemie 135:203-248.

García-Fernández, C.; Garcia, S. M. L. \& Garcia, R. N. 2001. Changes in the oviducts after fertilization of the cattle tick Boophilus microplus (Canestrini, 1887) (Acari: Ixodidae) Invertebrate Reproduction and Development 39(2):87-98.

García-Fernández, C.; Garcia, S. M. L.; Schneider, F. L.; Severino, A. G. \& Wilkelmann, E. C. 1999. Regionalization of oviducts in Boophilus microplus (Canestrini, 1887) (Acari: Ixodidae) and its potential significance for fertilization. Revista Brasileira de Biologia 59(4):653-661.

Geigy, R. \& Wagner, O. 1957. Ovogenese und Chromosomenverhältnisse bei Ornithodoros moubata. Acta Tropica 14:88-91.

KHALIL, G. M. 1969. Biochemical and physiological studies of certain ticks (Ixodidae). Gonad development and gametogenesis in Argas (Persicargas) arboreus Kaiser, Hoogstraland Khols (Argasidae). The Journal of Parasitology 55:1278-1297.

1970. Biochemical and physiological studies of certain ticks (Ixodoidea). Gonad development and gametogenesis in Hyalomma (H.) anatolicum excavatum Koch (Ixodidae). The Journal of Parasitology 56(3): 596-610.

LA Cour, L. F. 1941. Acetic-orcein stain. Stain Technology 16:169-74.

Lees, A. D. \& Beament, J. W. 1948. An egg-waxing organ in ticks. Quarterly Journal of Microscopical Science 89:291-332.

Oliver, J. H. JR. 1974. Symposium on reproduction of arthropods of medical and veterinary importance. IV. Reproduction in ticks (Ixodoidea). Journal of Medical Entomology 11(1):26-34.

Oliver, J. H., JR. 1982. Reproduction: sperm development and cytogenetics. In: Obenchain, F. D. \& Galun, R. eds. Physiology of ticks. Oxford, Pergamon. p. 245-273.

Oliver, J. H., JR \& Brinton, L. P. 1973. Sperm maturation in ticks: an example of capacitation in invertebrates. In: 
International Congress of Acarology of Prage Academie, $3^{\text {rd }}$, Prage, 1973. Proceedings... Prage, W. Junk. p.733-737.

Oppermann, E. 1935. Die Entstehung der Riesenspermien von Argas columbarum (Shaw) (reflexus F.). Zeitschrift für Mikroskopisch Anatomie Forschung 37:538-560.

Pieczarka, J. C.; Nagamachi, C. Y.; Barros, R. M. S. \& Mattevi, M. S. 1996. Analysis of constitutive heterochromatin by fluorochromes and in situ digestion with restriction enzymes in species of the group Callithrix argentata (Callitrichidae, Primates). Cytogenetics and Cell Genetics 72:325330 .

Pinkerton, A. M.; Hall, J. D. \& Shepherd, J. 1982. Scanning electron microscopy of post-ejaculatory spermiogenesis in the tick Ornithodoros moubata. Tissue and Cell 14(4): 785-797.

Reger, J. F. 1963. Spermiogenesis in the tick Amblyomma dissimili as revealed by electron microscopy. Journal of Ultrastructure Research 8:607-621.

__. 1974. The origin and fine structure of cellular processes in spermatozoa of the tick Dermacentor andersoni. Journal of Ultrastructural Research 48:420-434.

Roshdy, M. A. 1961. Observations by electron microscopy and other methods on the intracellular rickettsialike microorganisms in Argas persicus Oken (Ixodoidea, Argasidae). Journal of Insect Pathology 3:148-66.

Rothschild, F. R. S. 1961. Structure and movement of tick spermatozoa (Arachinida, Acari). Quarterly Journal of Microscopical Science 102:239-247.

Samsom, K. 1909. Zur spermiohistiogenese der zecken. Sitzungsbericht Geschift Naturforschung Freunde 8:486-99.
Schweizer, D. 1980. Simultaneous fluorescent staining of R bands and specific heterochromatic regions (DA/DAPI bands) in human chromosomes. Cytogenetics and Cell Genetics 27:190-193.

1981. Counterstain-enhanced chromosome banding. Human Genetics 57:1-14.

Sharma, G. P. 1944. Studies on spermatogenesis in ticks. Proceedings of the National Science of India 10:305316.

Sokolov, I. I. 1956. The problem of fertilization in ixodid ticks. Zoologichesky Zhurnal 35:511-528.

Sonenshine, D. E. 1991. The female reproductive system. In: Obenchain, F. D. \& Galun, G. D. eds. Biology of ticks. Oxford, Oxford University Press. v.1, p.281-304.

Suleiman, A. \& Brown, G. 1978. Spermiogenesis in the dog tick Dermacentor variabilis (Say). Iowa State Journal Research 51(2):93-108.

Till, W. M. 1961. A contribution to the anatomy and histology of the brown ear tick Rhipicephalus appendiculatus Neumann. Memories of Entomological Society of South Africa 6:1-124.

Tuzet, O. \& Millot, J. 1937. Recherches sur la spermiogènese des Ixodes. Bulletin Biologique de la France et de la Belgique 71:190-205.

WagneR-Jevseenko, O. 1958. Fortpflanzung bei Ornithodoros moubata und genitale vebertragung von Borrelia duttoni. Acta Tropica 15:118-168.

Wüest, J.; El Said, A.; Swiderski, Z. \& Aeschlimann, A. 1978. Morphology of the spermatid and spermatozoon of Amblyomma hebraeum Koch (Acarina; Ixodidae). Zeitschrift für Parasitenkunde 55:91-99. 